\title{
Siomycin A induces reactive oxygen species-mediated cytotoxicity in ovarian cancer cells
}

\author{
XIULAN SHAO, FENGYING ZHANG, XIANG GAO and FENGYING XU \\ Department of Obstetrics and Gynecology, The Hospital of Tinglin, Shanghai 201505, P.R. China
}

Received April 5, 2020; Accepted January 14, 2021

DOI: 10.3892/ol.2021.12692

\begin{abstract}
Ovarian cancer is one of the leading causes of cancer-related death among women worldwide and accounts for $4 \%$ of all cancer cases in female patients. To date, ovarian cancer has the poorest prognosis among all types of gynecological cancer; thus, it is necessary to identify prospective therapeutic options. Previous studies have demonstrated the involvement of reactive oxygen species (ROS) in the cytotoxicity of various anticancer drugs against several types of carcinoma, including ovarian cancer. The present study aimed to investigate the anticancer effects of Siomycin A, a thiopeptide antibiotic, on the ovarian cancer cell lines PA1 and OVCAR3. To determine the viability of these cells following exposure to Siomycin A, the MTT assay was used, and apoptosis was determined by ELISA. In addition, mitochondrial membrane potential was determined by JC1 staining, and cellular ROS levels were assessed by dichlorodihydrofluorescein diacetate staining in the presence and absence of antioxidant NAC. The subsequent levels of antioxidant enzymes and glutathione were also determined following Siomycin A treatment in the two cell lines. A combination study with Siomycin A and cisplatin indicated enhanced efficiency of the drugs on ovarian cancer cell viability. The results of the present study also demonstrated that Siomycin A induced ROS production, inhibited the major antioxidant enzymes, including catalase, superoxide dismutase, glutathione peroxidase, glutathione reductase and intracellular GSH in PA1 and OVCAR3 cells, and inhibited the cell viability with an $\mathrm{IC}_{50}$ of $\sim 5.0$ and $2.5 \mu \mathrm{M}$ after $72 \mathrm{~h}$ respectively compared with the untreated controls. Additionally, the Siomycin A-induced ROS production further targeted apoptotic cell death by impairing the mitochondrial membrane potential and modulating the levels of pro- and antiapoptotic proteins compared with those in the corresponding control groups. The administration of the antioxidant $\mathrm{N}$-acetylcysteine
\end{abstract}

Correspondence to: Dr Fengying Xu, Department of Obstetrics and Gynecology, The Hospital of Tinglin, 78 Siping North Street, Tinglin, Jinshan, Shanghai 201505, P.R. China

E-mail: kiannaolsonqvo@yahoo.com

Key words: ovarian cancer, Siomycin A, mitochondrial membrane potential, reactive oxygen species, antioxidant enzymes, apoptosis significantly abrogated the cytotoxic effects of Siomycin A. In conclusion, the results of the present study demonstrated the role of ROS in Siomycin A-mediated cytotoxicity in ovarian cancer cells.

\section{Introduction}

Ovarian cancer (OC) is the seventh most common type of cancer globally, and the third most common type of cancer among women (1). Worldwide, 240,000 women get diagnosed with OC each year, and the 5-year survival rate is $<45 \%$ (2). The incidence rates of OC are alarmingly increasing, even in countries considered to have a low OC incidence $(3,4)$. A number of risk factors are associated with epithelial OC, among which the major factors are reproductive and hormonal parameters (5). The low survival rate of OC is associated with late diagnosis and also the probability of disease recurrence in the majority of patients after primary or first line therapy completion (6).

Among the types of OC, screening studies have reported that low-grade serous ovarian tumors are more slow-growing, but more chemoresistant compared with high-grade serous ovarian tumors (7). OCs present with high molecular heterogeneity and genetic changes, which may help translate these morpho-molecular concepts to therapeutic strategies (8). A number of first-line therapeutic interventions have been developed for OC treatment; a nitrogen mustard alkylating agent was the initial strategy, and the current standard of care includes cyto-reductive surgery followed by combination taxane-platinum treatment (9). However, it has been observed that $\sim 80 \%$ of the treated individuals experience chemoresistant recurrence $(9,10)$. Novel non-platinum based chemotherapeutic drugs and targeted molecular therapies may have a major impact on the treatment and remission of OC.

Siomycin A is a thiazole compound antibiotic containing sulfur with specific activity against Gram-positive bacteria (11). A number of other thiazole antibiotics have been studied (e.g. thiostrepton, thiopeptin and sporangiomycin), and the results have demonstrated that these compounds block translation at the translocation step by binding to $23 \mathrm{~S}$ rRNA on the 50S ribosomal subunit (12). Previous studies have attempted to elucidate the role of Siomycin A as a novel compound for cancer treatment. Siomycin A has been demonstrated to act as a potent oncogenic protein forkhead box M1 inhibitor in human lung adenocarcinoma, glioblastoma, 
nasopharyngeal carcinoma, melanoma and acute $\mathrm{T}$ cell lymphoma (13). In addition, Siomycin A may serve a proapoptotic role in epithelial cancer cells, inducing apoptosis by lysosomal permeabilization (14); however, to date, the roles of this compound have not been studied in OC cells. Therefore, the present study aimed evaluate for the first time the role of Siomycin A as a potential anticancer drug in OC cells and to identify the mechanism of action underlying its effects on cell proliferation, apoptosis and mitochondrial membrane status in PA1 and OVCAR3 cells.

\section{Materials and methods}

Cell culture. OC cell lines PA-1 (PA1; (ATCC ${ }^{\circledR}$ CRL-1572 ${ }^{\mathrm{TM}}$ ) and NIH:OVCAR-3 (OVCAR3; ATCC ${ }^{\circledR}$ HTB-161 $^{\mathrm{TM}}$ ), and a normal lung fibroblast cell line WI-38 (ATCC ${ }^{\circledR} \mathrm{CCL}^{-75^{\mathrm{TM}}}$ ) were purchased from ATCC and cultured in Dulbecco's modified Eagle's medium (DMEM; Gibco; Thermo Fisher Scientific, Inc.) supplemented with 10\% FBS (Gibco; Thermo Fisher Scientific, Inc.), $100 \mathrm{U} / \mathrm{ml}$ penicillin and $100 \mu \mathrm{g} / \mathrm{ml}$ streptomycin at $37^{\circ} \mathrm{C}$ in a humidified $5 \% \mathrm{CO}_{2}$ chamber (HF90; Heal Force Bio-Meditech Holdings Ltd.). Cells were observed under an inverted phase contrat microscope (Zeiss Axiovert. A1; magnification, $\mathrm{x} 20$ ).

Cell viability assay. Cell viability was assessed by MTT assay. PA1 and OVCAR3 cells were seeded into 96-well plates at a density of $\sim 1 \times 10^{4}$ cells/well and treated with $0-100 \mu \mathrm{M}$ Siomycin A for 24, 48 or $72 \mathrm{~h}$. Subsequently, $20 \mu \mathrm{l}$ of MTT (Sigma-Aldrich; Merck KGaA) solution, from the stock of $5 \mathrm{mg} / \mathrm{ml}$ in PBS, was added to each well and incubated for $3 \mathrm{~h}$ at $37^{\circ} \mathrm{C}$. The purple formazan crystals were dissolved using $100 \mu \mathrm{l}$ of DMSO and cell viability was analyzed at a wavelength of $570 \mathrm{~nm}$, using a MultiskanEX plate reader (Labsystems Diagnostics Oy) (15). The cytotoxicity of Siomycin A to normal cells was determined by the same method on cultured WI-38 cells. Cell viability of PA1 and OVCAR3 cells were also assessed using the anticancer drug cisplatin (Sigma-Aldrich; Merck KGaA; 0-50 $\mu \mathrm{M}$ ) (and following co-treatment with the $\mathrm{IC}_{50}$ dose of cisplatin and Siomycin A for $48 \mathrm{~h}$ using MTT assay. All experiments were performed in triplicate.

Detection of apoptosis by ELISA. Induction of apoptosis in Siomycin A-treated OC cells was determined by the Cell Death Detection ELISA ${ }^{\text {PLUS }}$ (Sigma-Aldrich; Merck $\mathrm{KGaA}$ ) according to the manufacturer's instructions as well as a published protocol (16). Briefly, PA1 and OVCAR3 cells $\left(\sim 1 \times 10^{4}\right.$ cells $\left./ \mathrm{ml}\right)$ of $60 \mathrm{~mm}$ plates were treated with 2.5 and $5 \mu \mathrm{M}$ Siomycin A for $48 \mathrm{~h}$. Following treatment, untreated and Siomycin A-treated cells were harvested, lysed with RIPA lysis buffer (Thermo Fischer Scientific, USA) and subjected to subcellular fractionization using the components of the kit. The cytoplasmic fraction was collected by centrifugation at $10,000 \mathrm{x} \mathrm{g}$ at $4^{\circ} \mathrm{C}$ for $15 \mathrm{~min}$, and $\sim 20 \mu \mathrm{l}$ of the lysate containing $15 \mu \mathrm{g}$ protein as assessed by the Bradford assay, was added to the streptavidin-coated microplate. Subsequently, $80 \mu 1$ of buffer mixture containing anti-histone-biotin and anti-DNA peroxidase was added, and the reaction mixture was incubated for $2 \mathrm{~h}$ at room temperature with continuous shaking. Finally, the chromogenic substrate 2,2'-azino-di-(3-ethylbenzthiazoline-6-sulfonic acid) was added to develop the color, and the absorbance was measured at $405 \mathrm{~nm}$ using an ELISA reader (Molecular Devices, LLC).

Determination of mitochondrial membrane potential. PA1 and OVCAR3 cells $\left(\sim 1 \times 10^{4}\right.$ cells $\left./ \mathrm{ml}\right)$ of $60 \mathrm{~mm}$ plates were treated with 2.5 and $5 \mu \mathrm{M}$ Siomycin A for $48 \mathrm{~h}$. Following treatment, the cells were incubated with $3 \mu \mathrm{g} / \mathrm{ml} \mathrm{JC}-1$ (5,5',6,6'-tetrachloro-1,1',3,3'-tetraethylbenzimidazolcarbocyanine iodide; Abcam) for $20 \mathrm{~min}$ at $37^{\circ} \mathrm{C}$ (17). The cells were washed with chilled PBS, and JC1 fluorescence was assessed at 530 and $590 \mathrm{~nm}$ using a Fluoroskan microplate fluorimeter (Thermo Fischer Scientific, Inc.). The ratio of red/green fluorescence intensity (aggregate/monomer) was analyzed using the instrument Scanlt 2.0.7 software. All experiments were performed in triplicate.

ROS detection by 2',7'-dichlorodihydrofluorescein diacetate (DCFDA) assay. Cultured PA1 and OVCAR3 cells $\left(\sim 1 \times 10^{4}\right.$ cells $\left./ \mathrm{ml}\right)$ of $60 \mathrm{~mm}$ plates were treated with Siomycin A in two sets: i) $5 \mu \mathrm{M}$ for $6,12,24$ and $48 \mathrm{~h}$; and ii) $2.5,5$ and $10 \mu \mathrm{M}$ for $24 \mathrm{~h}$. Following treatment, the cells were stained with $10 \mu \mathrm{M}$ DCFDA (Abcam) for $30 \mathrm{~min}$ in the dark at room temperature (18). Subsequently, the cells were washed twice with cold PBS, and fluorescence was assessed at the excitation/emission wavelengths of 485/535 nm using a Fluoroskan microplate fluorimeter. All experiments were performed in triplicate. For ROS generation-associated assays, the cells were pretreated with $200 \mu \mathrm{M} \mathrm{N}$-acetylcysteine (NAC) for $6 \mathrm{~h}$, followed by the treatment with the putative drug Siomycin A, as aforementioned.

Estimation of ROS scavenging enzymes and intracellular GSH content. The PA1 and OVCAR3 cells treated with Siomycin A were collected and resuspended in $200 \mu \mathrm{l}$ RIPA lysis buffer (Thermo Fischer Scientific, Inc.) for lysis and subsequent extraction of cellular proteins. The cells were sonicated on an ice bath, thrice for $15 \mathrm{sec}$ each pulse to extract the cellular proteins from the supernatant, and were used for subsequent antioxidant assays. All experiments were performed in triplicate.

Catalase (CAT) activity. A total of $20 \mu \mathrm{l}$ cell extract was added to $100 \mu \mathrm{l}$ sample buffer $(50 \mathrm{mM}$ potassium phosphate buffer, $\mathrm{pH}$ 7.0) and mixed with $180 \mu \mathrm{l} 30 \mu \mathrm{M} \mathrm{H}_{2} \mathrm{O}_{2}$ (cat. no. 107209; MilliporeSigma). For blank setup, $20 \mu \mathrm{l}$ sample buffer was used instead of the cell extract. The decomposition of $\mathrm{H}_{2} \mathrm{O}_{2}$ to $\mathrm{H}_{2} \mathrm{O}$ and $\mathrm{O}_{2}$ by CAT present in the cell lysates was monitored at $240 \mathrm{~nm}$ using a T8001S Double beam UV/Vis spectrophotometer (Shanghai Yoke Instrument Co., Ltd.). Catalase enzyme activity was calculated as the number of $\mu \mathrm{mol}$ of $\mathrm{H}_{2} \mathrm{O}_{2}$ consumed per min per $1 \mathrm{mg}$ protein against a standard curve (19).

Superoxide dismutase (SOD) activity. A total of $2.35 \mathrm{ml}$ buffer A [0.1 mol/1 Tris-HCl (cat. no. 648313; MilliporeSigma) buffer solution with $1 \mathrm{mM}$ EDTA (MilliporeSigma), $\mathrm{pH}$ 8.2] was added to $2.00 \mathrm{ml}$ deionized water; subsequently, $0.15 \mathrm{ml}$ buffer $\mathrm{B}(4.5 \mathrm{mmol} / \mathrm{l}$ pyrogallol solution in $\mathrm{HCl}$; cat. no. 100612; MilliporeSigma) was added, and the solution 


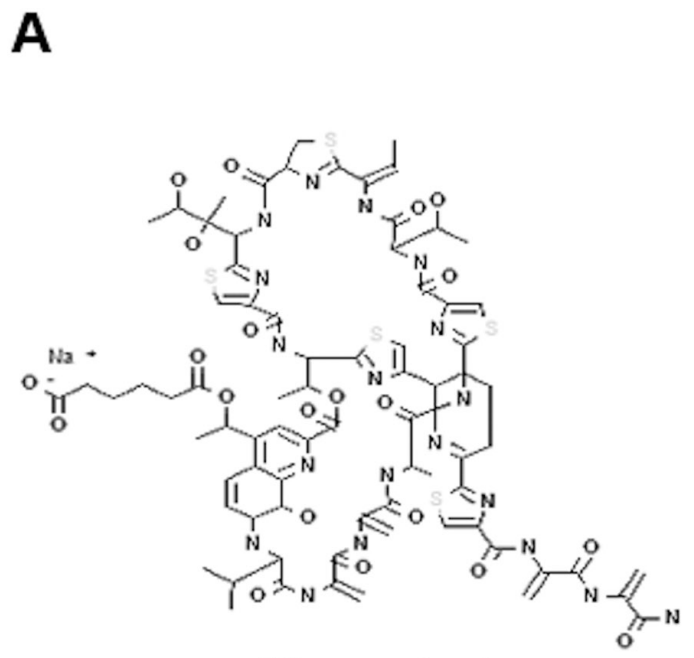

Siomycin A

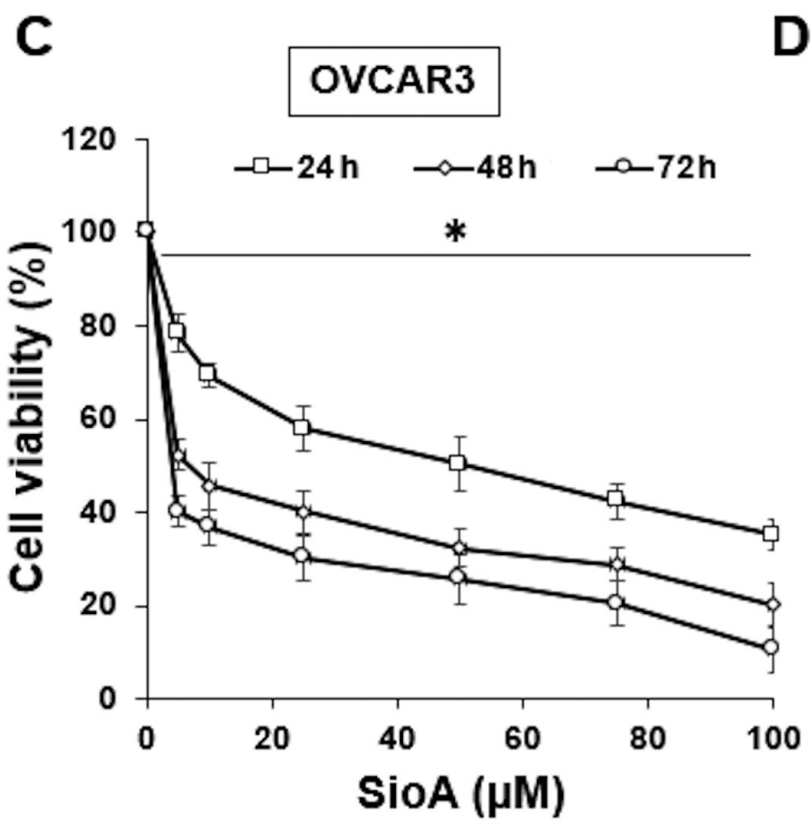

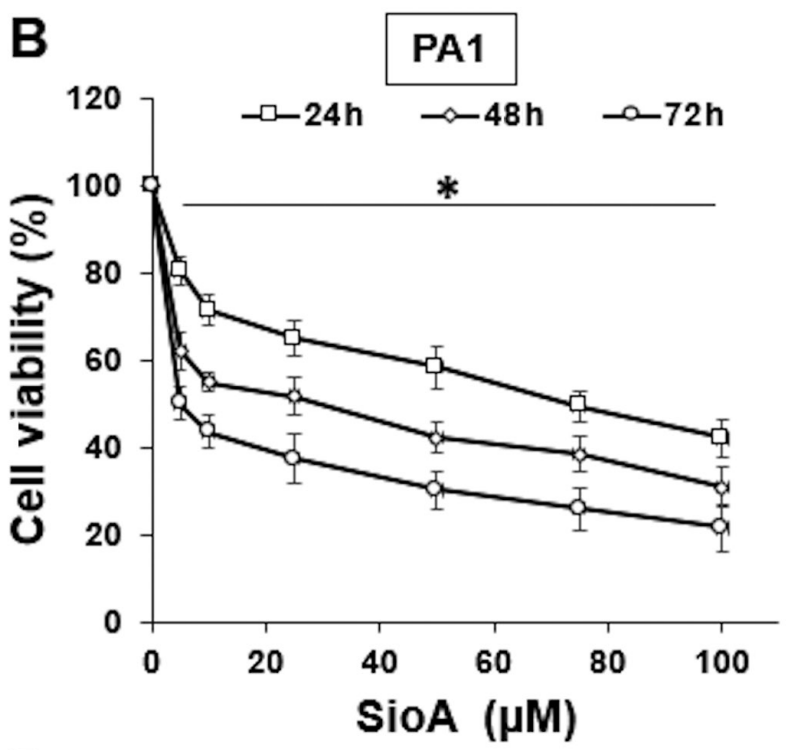

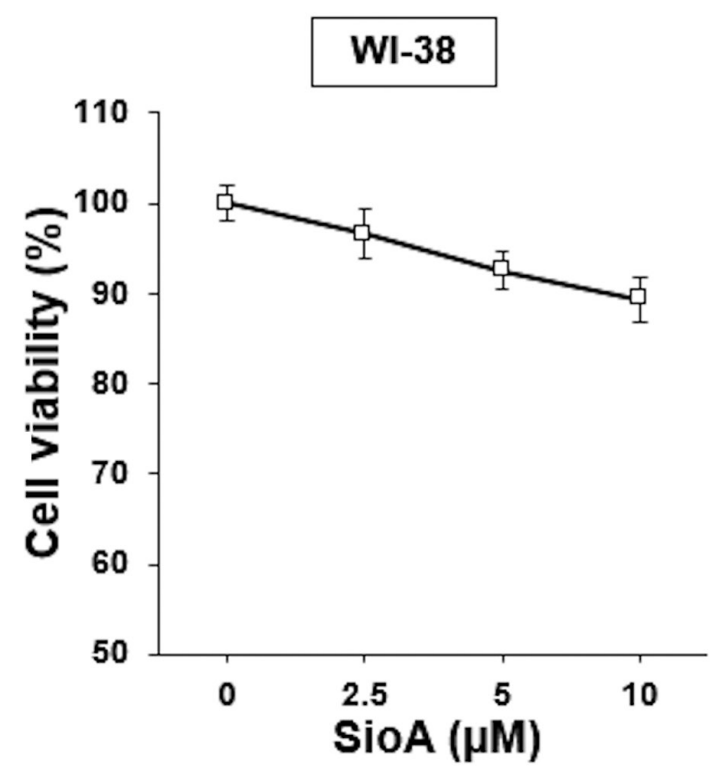

Figure 1. Cytotoxicity of SioA on ovarian cancer cells. (A) Chemical structure of SioA. (B and C) MTT assay results demonstrated the loss of (B) PA1 and (C) OVCAR3 cell viability following treatment with 0-100 $\mu \mathrm{M}$ SioA for 24, 48 and $72 \mathrm{~h}$. (D) Cell viability assay of WI-38 lung fibroblast cells treated 2.5, 5 and $10 \mu \mathrm{M}$ with SioA for 72 h. $\mathrm{n}=3$. ${ }^{*} \mathrm{P}<0.05$. SioA, Siomycin A.

was vortexed for $2 \mathrm{~min}$ at room temperature. Absorbance was measured at $420 \mathrm{~nm}$ in 1-min intervals. The difference in absorbance between two aliquots, $\Delta \mathrm{A} 420$ (min -1), indicated the rate of pyrogallol autoxidation in the blank sample. For all experimental samples, the same procedure was followed with the addition of sample before buffer B, and absorbance was recorded using a T8001S Double beam UV/Vis spectrophotometer. The SOD enzyme activity was based on the autooxidation rate of pyrogallol and the inhibition of this autooxidation by SOD, where $50 \%$ inhibition corresponded to one unit of enzyme activity (20).

Glutathione peroxidase (GPx) activity. A total of $10 \mu$ l sample buffer (50 mM potassium phosphate buffer, $\mathrm{pH}$ 7.0) was added to potassium phosphate buffer $(170 \mu \mathrm{l})$ with $1 \mathrm{mM}$ EDTA and 2 mM sodium azide ( $\mathrm{pH} 7.0$; cat. no. 106688; MilliporeSigma) and used as the blank sample. For all experimental samples,
$10 \mu \mathrm{l}$ cell extract was added in place of sample buffer. A total of $90 \mu \mathrm{l}$ master mix with $30 \mu \mathrm{l}(10 \mathrm{mM})$ glutathione (GSH; cat. no. 3541 MilliporeSigma); mixed with $30 \mu \mathrm{l}(2.4 \mathrm{U} / \mathrm{ml})$ glutathione reductase (cat. no. 359960; MilliporeSigma) and $30 \mu 1$ nicotinamide adenine dinucleotide phosphate $[1.5 \mathrm{mM}$ NADPH (cat. no. 481973; MilliporeSigma) in $0.1 \%$ sodium bicarbonate (cat. no. 106329; MilliporeSigma) solution] was added to each sample and incubated at $37^{\circ} \mathrm{C}$ for $10 \mathrm{~min}$. A total of $30 \mu \mathrm{l}(2 \mathrm{mM}) \mathrm{H}_{2} \mathrm{O}_{2}$ was added to each sample and the decomposition of $\mathrm{H}_{2} \mathrm{O}_{2}$ was monitored by observing the rate of NADPH consumption at $340 \mathrm{~nm}$ for $10 \mathrm{~min}$ in a T8001S Double beam UV/Vis spectrophotometer. The GPx enzyme activity was calculated as NADPH (in $\mathrm{nM}$ ) consumed per min per $1 \mathrm{mg}$ protein (21).

Glutathione reductase (GR) activity. A total of $230 \mu$ l sample buffer (50 mM potassium phosphate buffer, $\mathrm{pH}$ 7.0) was added 
A
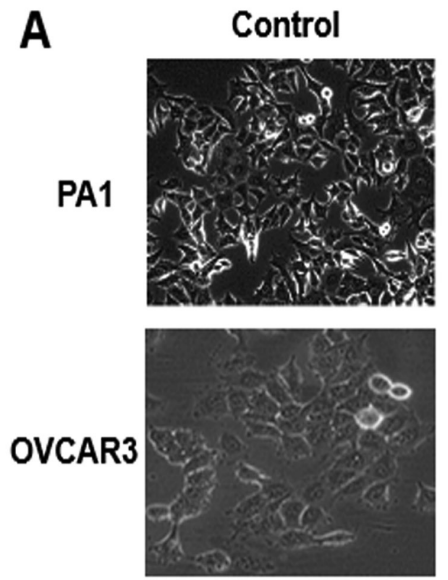

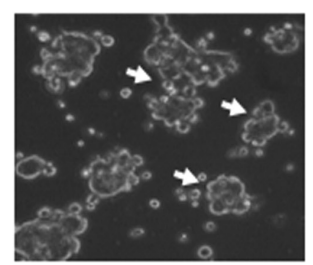

$\operatorname{SioA}(5 \mu \mathrm{M})$
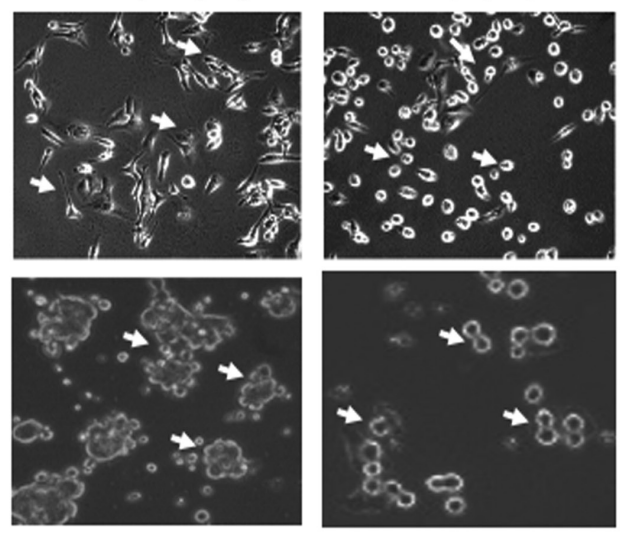

B

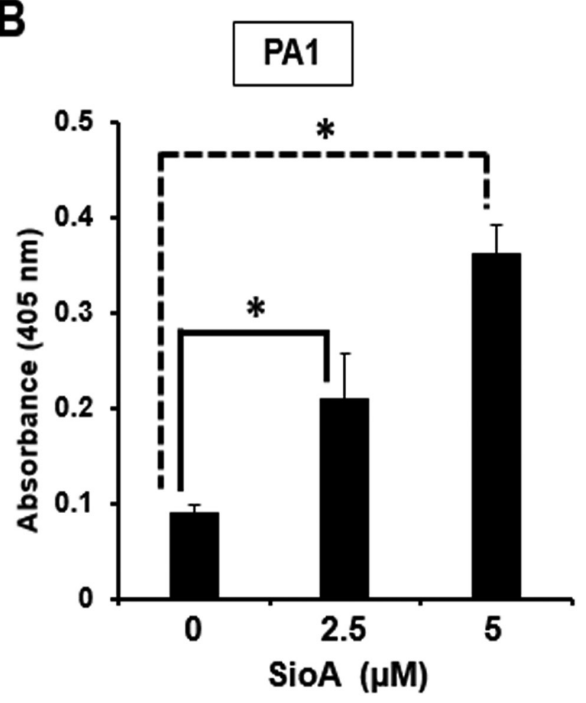

C

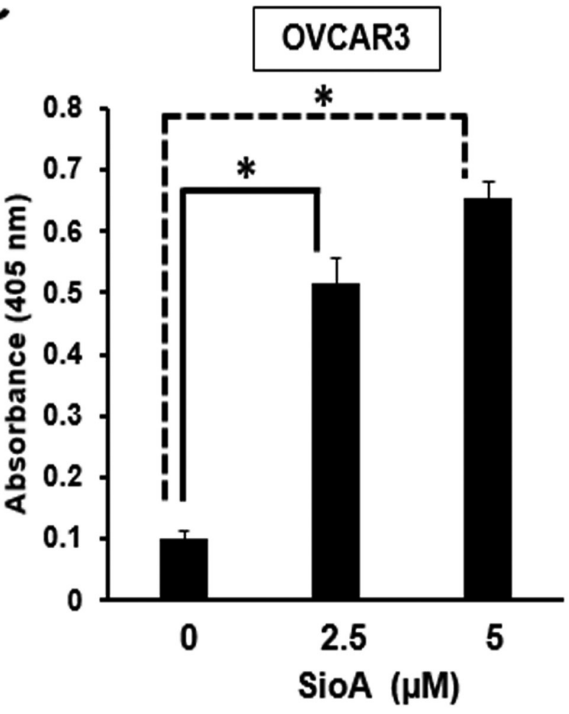

Figure 2. Induction of apoptosis and morphological changes in ovarian cancer cells following SioA treatment. (A) PA1 and OVCAR3 cells were treated with 2.5 and $5 \mu \mathrm{M}$ SioA for $48 \mathrm{~h}$, and morphological alterations of the cells (arrowheads indicated) were observed by inverted phase contrast microscopy (magnification, $\mathrm{x} 20$ ). (B) PA1 and (C) OVCAR3 cells were treated with 2.5 and $5 \mu \mathrm{M}$ SioA for $48 \mathrm{~h}$, and apoptosis was determined using ELISA. n=3. ${ }^{\mathrm{P}}<0.05$. SioA, Siomycin A.

to $40 \mu \mathrm{l}$ potassium phosphate buffer with $1 \mathrm{mM}$ EDTA and used as the blank sample. A total of $10 \mu \mathrm{l}$ cell extract and $30 \mu 1$ (20 mM) glutathione disulfide (cat. no. 3542; MilliporeSigma) was added to the mixture for each experimental sample. All samples were incubated at $37^{\circ} \mathrm{C}$ for $3 \mathrm{~min}$, and the reaction was started by adding $30 \mu 11.5 \mathrm{mM}$ NADPH in $0.1 \%$ sodium bicarbonate. The subsequent consumption of NADPH was monitored at $340 \mathrm{~nm}$ for $5 \mathrm{~min}$ at $37^{\circ} \mathrm{C}$ in a T8001S Double beam UV/Vis spectrophotometer. The GR enzyme activity was calculated as NADPH (in $\mathrm{nM}$ ) consumed per min per $1 \mathrm{mg}$ cellular protein (21).

Intracellular GSH content. A total of $200 \mu \mathrm{l}$ of assay mixture [0.84 mM 5,5' dithiobis-(2-nitrobenzoic acid) (DTNB; cat. no. 322123; MilliporeSigma) and $0.28 \mathrm{mM} \mathrm{NADPH}$ dissolved in $100 \mathrm{mM}$ sodium phosphate buffer, $\mathrm{pH} 7.5$, with $5 \mathrm{mM}$ EDTA] was added to $20 \mu \mathrm{l}$ sample buffer $(50 \mathrm{mM}$ potassium phosphate buffer, $\mathrm{pH}$ 7.0) in a quartz cuvette and incubated at $37^{\circ} \mathrm{C}$ for $5 \mathrm{~min}$. For the experimental samples, $20 \mu \mathrm{l}$ cell extract was added instead of the sample buffer. The reaction was initiated by adding $40 \mu \mathrm{l}$ glutathione reductase, and the reduction of DTNB and formation of TNB was monitored for $10 \mathrm{~min}$ at $412 \mathrm{~nm}$ using a T8001S Double beam $\mathrm{UV} / \mathrm{Vis}$ spectrophotometer (22). The GSH content was determined with reference to a GSH standard curve using known concentrations of GSH $(0-50 \mu \mathrm{M})$.

Preparation of the cytosolic extract from PAI and OVCAR3 cells. PA1 and OVCAR3 cells were seeded at a density of $1 \times 10^{4}$ cells $/ \mathrm{ml}$, grown to confluency in $60 \mathrm{~mm}$ plates and treated with 2.5 and $5 \mu \mathrm{M}$ Siomycin A treatment for $48 \mathrm{~h}$. Following treatment, the adherent cells were detached using trypsin (Sigma-Aldrich; Merck KGaA) and subsequently centrifuged in various buffers to separate the cytosolic phase (supernatant of final step) from the rest of the cell pellet as previously described (23). The amount of total protein from the cytosolic extracts of control and treated PA1 and OVCAR3 cells was estimated using the Bradford reagent (Abcam), and equal amounts $(40 \mu \mathrm{g})$ of protein were loaded in each well for the detection of 
A
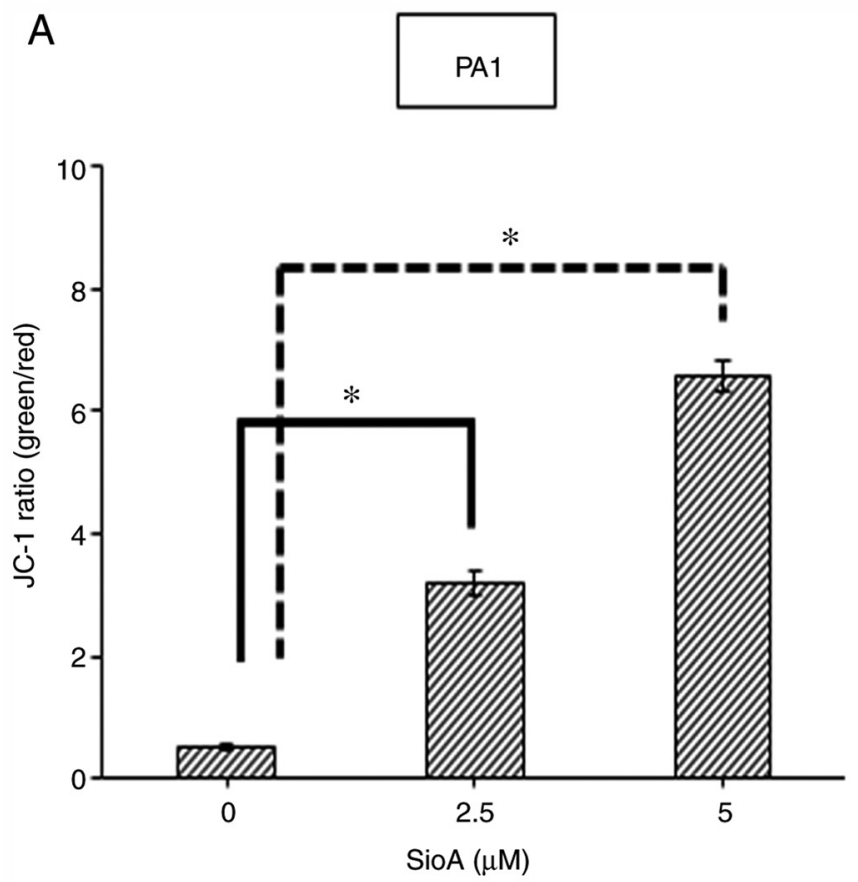

B

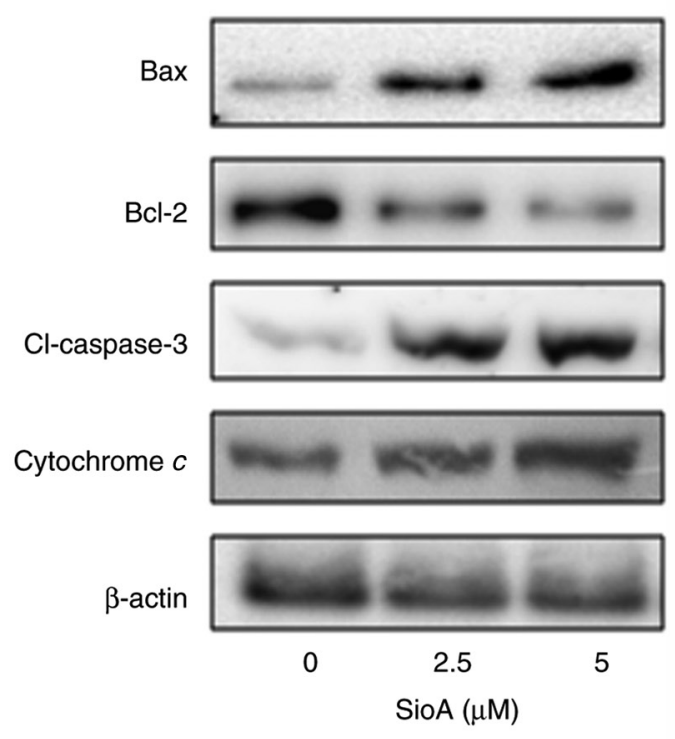

C
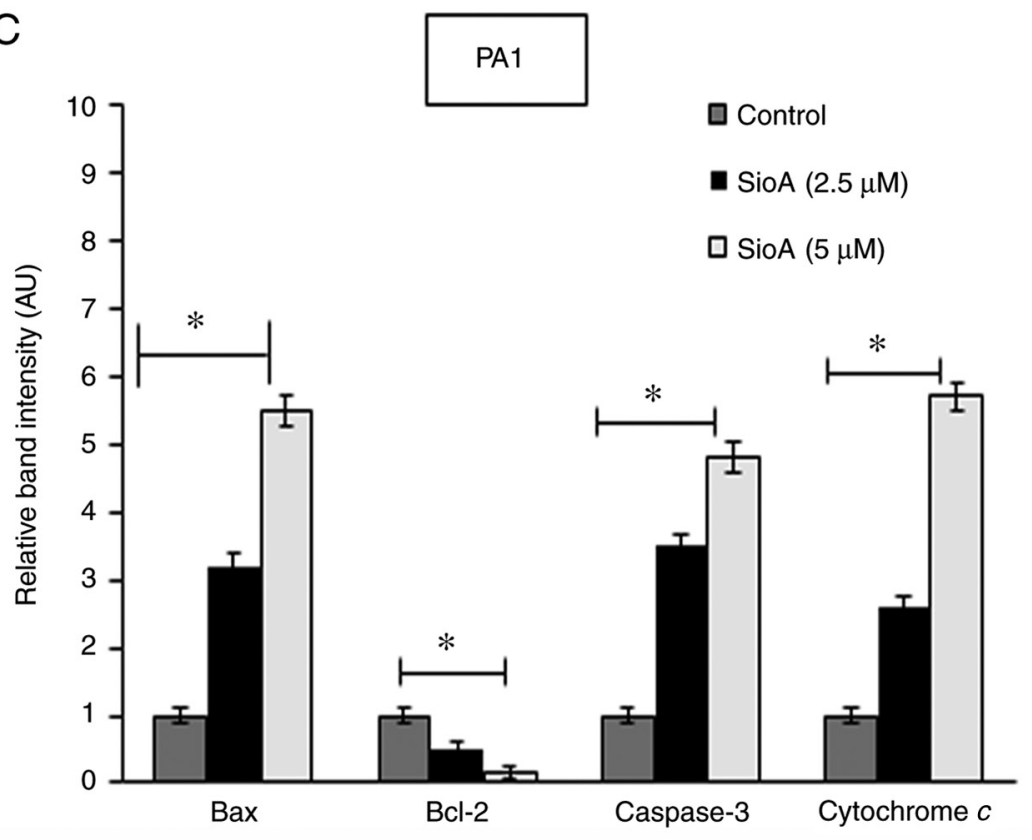

Figure 3. Mitochondrial membrane potential and the levels of pro- and antiapoptotic markers in SioA-treated PA1 cells. (A) JC1 staining results of 2.5 and $5 \mu \mathrm{M}$ SioA-treated ( $48 \mathrm{~h})$ PA1 cells compared with the untreated control. (B) Western blot analysis demonstrated increased protein expression levels of Bax, cl-caspase-3 and cytochrome $c$ in SioA-treated PA1 cells compared with those in the untreated control group. (C) Relative band intensities of the proteins. $\beta$-actin was used as the loading control. $n=3$. ${ }^{*} \mathrm{P}<0.05$. SioA, Siomycin A; cl, cleaved.

cytochrome $c$ by western blotting. All experiments were performed in triplicate.

Western blot analysis. PA1 and OVCAR3 cells in $60 \mathrm{~mm}$ plates at a concentration of $\sim 1 \times 10^{4}$ cells $/ \mathrm{ml}$ were treated with 2.5 and $5 \mu \mathrm{M}$ of Siomycin A for $48 \mathrm{~h}$. Following treatment, the cells were incubated in lysis buffer (Thermo Fischer Scientific, Inc.). The total protein concentrations were determined by Bradford assay using a standard curve, and equal amount of proteins $(30-50 \mu \mathrm{g})$ were separated by $10-12 \%$ SDS-PAGE. Following separation, the cellular proteins were transferred to nitrocellulose membranes (MilliporeSigma) and blocked with $5 \%$ skimmed milk for $1 \mathrm{~h}$ at room temperature. The membranes were incubated with primary antibodies (all 1:1,000 dilution) against Bax (cat. no. sc-7480), Bcl2 (cat. no. sc-492), cleaved caspase -3 (cat. no. CST- 9661), cytochrome $c$ (cat. no. sc-13156) and $\beta$-actin (cat. no. sc-47778) for $16 \mathrm{~h}$ at $4^{\circ} \mathrm{C}$, followed by incubation with a corresponding horseradish peroxidase-linked secondary antibody (1:3,000 dilution; goat anti-mouse-HRP secondary antibody, cat. no. 32430 and goat anti-rabbit HRP secondary antibody, cat. no. 31460) Invitrogen; Thermo Fisher Scientific, Inc.)] for $2 \mathrm{~h}$ at room 
A

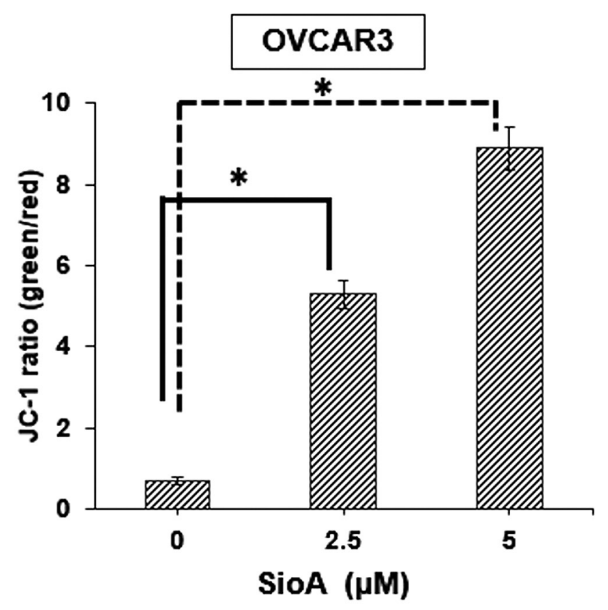

B

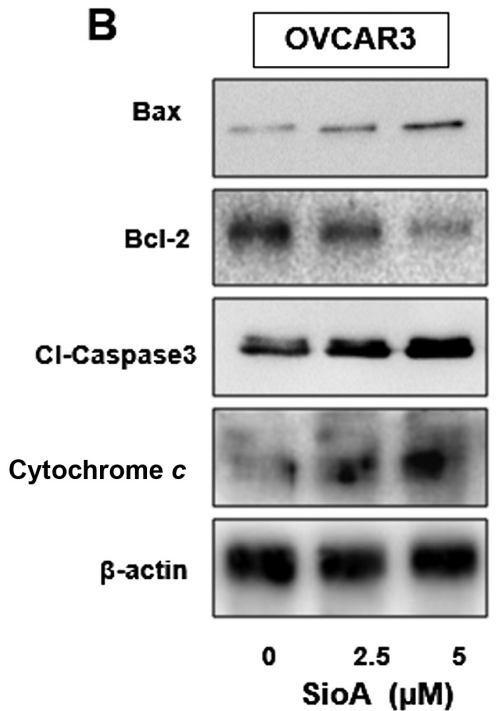

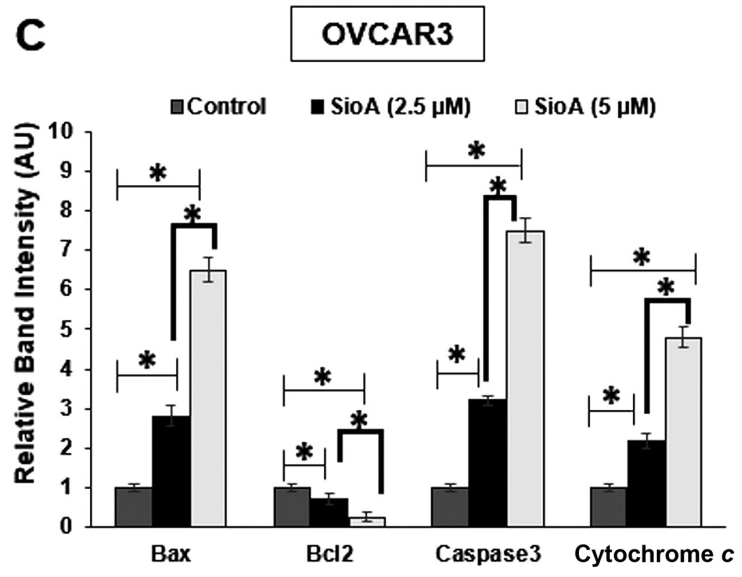

Figure 4. Mitochondrial membrane potential and the levels of pro- and antiapoptotic markers in SioA-treated OVCAR3 cells. (A) JC1 staining of 2.5 and $5 \mu \mathrm{M}$ SioA-treated (48 h) OVCAR3 cells demonstrated an increased green/red fluorescence ratio compared with that in the untreated control. (B) Western blot analysis demonstrated increased expression levels of Bax, cl-caspase-3 and cytochrome $c$ in SioA-treated OVCAR3 cells compared with those in the untreated control group. (C) Relative band intensities for the proteins. $\beta$-actin was used as the loading control. $n=3$. * $\mathrm{P}<0.05$. SioA, Siomycin A; cl, cleaved.

temperature and washed using TBS and TBST buffers (Tris buffer saline; BioRad Laboratories, Inc.). Bands were developed using the Clarity Western ECL substrate luminol assay kit (cat. no. 1705060; BioRad Laboratories, Inc.), and chemiluminescence was recorded in Chemidoc ${ }^{\mathrm{TM}}$ Gel Imaging System (Bio-Rad Laboratories, Inc.). The densitometric analysis was performed using ImageJ 1.52a software (National Institutes of Health). All experiments were performed in triplicate.

Statistical analysis. Data are presented as the mean \pm standard error of the mean of at least three independent experiments. Two-way ANOVA followed by Sidak's or Bonferroni correction was performed to analyze the effects of the dose of Siomycin A, NAC treatment and the interaction between the dose of Siomycin A and NAC. All other data were analyzed by one-way ANOVA followed by Tukey's test. GraphPad Prism 5.0 software (GraphPad Software, Inc.) was used for analysis. $\mathrm{P}<0.05$ was considered to indicate a statistically significant difference.

\section{Results}

Siomycin A inhibits proliferation and induces cytotoxicity in $O C$ cells. The present study evaluated the antitumor effects of the thiopeptide antibiotic Siomycin A (Fig. 1A) on OC cells. OC cell lines PA1 and OVCAR3 were treated with a 0-100 $\mu \mathrm{M}$ Siomycin A for 24, 48 and $72 \mathrm{~h}$. The results of the MTT assay demonstrated that Siomycin A decreased the PA1 and OVCAR3 cell viability and the effects appeared to increase at higher doses and longer incubation times (Fig. $1 \mathrm{~B}$ and $\mathrm{C}$ ), with the $\mathrm{IC}_{50}$ values at $5 \mu \mathrm{M}$ for PA1 cells and $2.5 \mu \mathrm{M}$ for OVCAR3 cells following 72 -h treatment $(\mathrm{P}<0.05)$. The cytotoxicity of Siomycin A in normal cells was also evaluated. Previous studies have used the human normal lung fibroblast WI-38 cell line to assess the cytotoxicity of anticancer drugs $(10,24,25)$. In the present study, WI-38 cells were treated with $0-10 \mu \mathrm{M}$ Siomycin A for $72 \mathrm{~h}$, and no significant loss of cell viability was determined by MTT assay (Fig. 1C). These results demonstrated that Siomycin A exerted an inhibitory effect on OC cells, and the low $\mathrm{IC}_{50}$ values indicated that it may be a potential option for treatment due to limited toxicity on the surrounding normal cells.

Siomycin A treatment alters morphology and induces apoptosis in OC cells. Treatment of PA1 and OVCAR3 cells with 2.5 and $5 \mu \mathrm{M}$ Siomycin A resulted in the alteration of the cellular morphology. The cells began to lose their spindle-shape nature and formed shrunken spherical structures upon treatment; the 
A
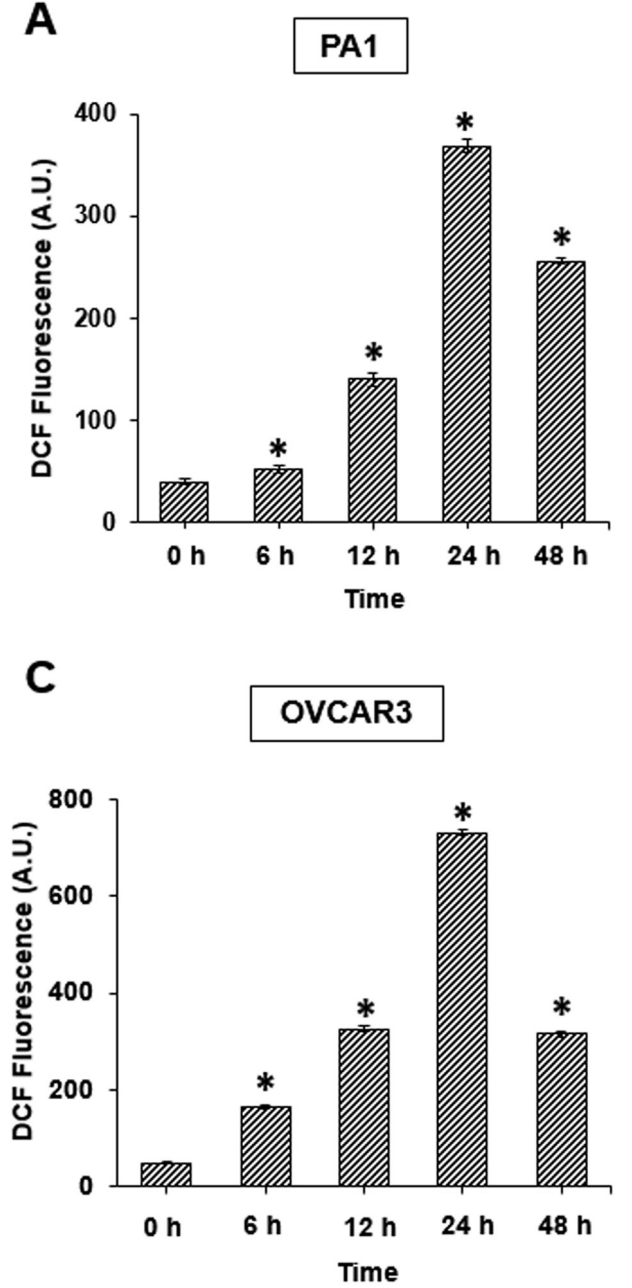

B

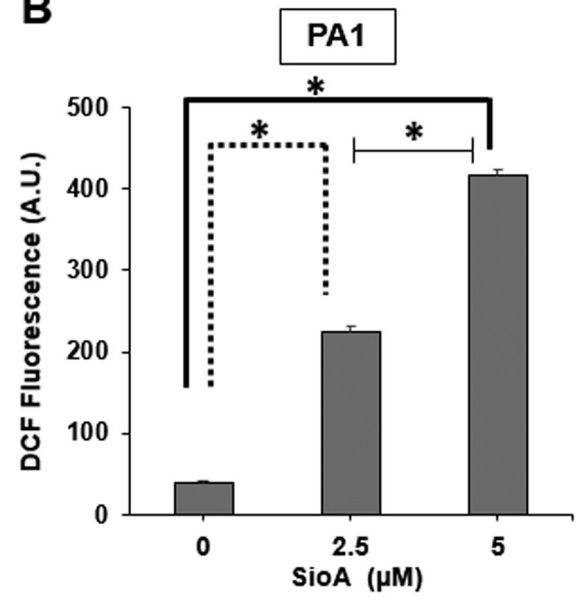

D

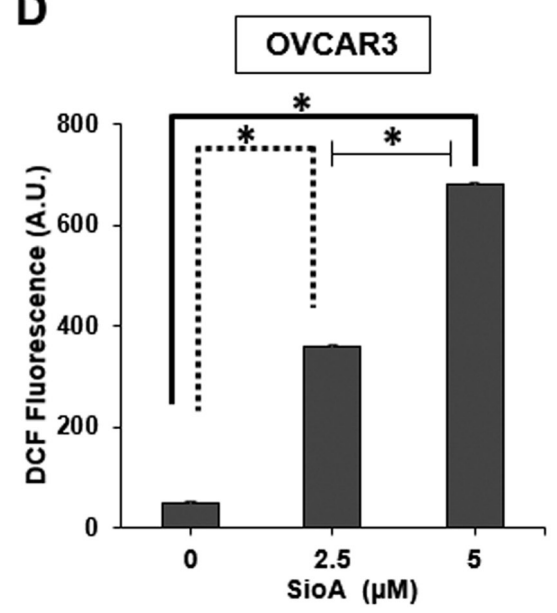

Figure 5. SioA induces ROS production in ovarian cancer cells. (A) The results of the DCFDA assay demonstrated a stable increase of ROS production in PA1 cells following $5 \mu \mathrm{M}$ SioA treatment between 6 and $24 \mathrm{~h}$. (B) ROS production increased between 2.5 and $5 \mu \mathrm{M}$ SioA treatment in PA1 cells at the $24 \mathrm{~h}$ time point, as demonstrated by the DCFDA assay. (C) DCFDA assay demonstrated a stable increase of ROS production in OVCAR3 cells following $5 \mu$ M SioA treatment between 6 and $24 \mathrm{~h}$. (D) ROS production increased between 2.5 and $5 \mu \mathrm{M}$ Siomycin A treatment in OVCAR3 cells at $24 \mathrm{~h}$, as demonstrated by the DCFDA assay. $\mathrm{n}=3$. * $\mathrm{P}<0.05$ vs. $0 \mu \mathrm{M}$ SioA. DCFDA, dichlorodihydrofluorescein diacetate; SioA, Siomycin A; ROS, reactive oxygen species.

change was moderate for $2.5 \mu \mathrm{M}$ and more prominent for $5 \mu \mathrm{M}$. The cell density also significantly decreased following treatment with $5 \mu \mathrm{M}$ Siomycin A in both cell lines (Fig. 2A). Siomycin A treatment of PA1 and OVCAR3 cells significantly induced of apoptosis at $48 \mathrm{~h}$, as determined by ELISA. In the presence of $2.5 \mu \mathrm{M}$ Siomycin A, the absorbance increased by 2.3-fold for PA1 and 5.1-fold for OVCAR3 cells, whereas following treatment with $5 \mu \mathrm{M}$ Siomycin $\mathrm{A}$, the increase in absorbance was $\sim 4$.0-fold for PA1 and 6.4-fold for OVCAR3 cells (Fig. 2B and $\mathrm{C} ; \mathrm{P}<0.05$.

These results demonstrated that Siomycin A exerted proapoptotic effects on the OC cell lines by initially altering the cell morphology and changing the adherent defined structures to rounded shrunken clots. These features, along with the reduced cell density and decreased viability, were indicative of apoptosis, which was further confirmed by ELISA to reveal that Siomycin A induced apoptosis, with high occurrence of cell death at $5 \mu \mathrm{M}$ for both PA1 and OVCAR3 cells.

Siomycin A treatment affects OC cell mitochondrial membrane potential and the levels of pro- and antiapoptotic markers. In order to determine the cellular changes that induce apoptosis in OC cells following Siomycin A treatment, the roles of mitochondria were examined. The changes in the mitochondrial membrane potential were analyzed by staining PA1 and OVCAR3 cells with the mitochondria-specific dye JC-1. Fluorimetric analysis of the Siomycin A-treated PA1 and OVCAR3 cells revealed a decrease in the red fluorescence population and a simultaneous increase in the green fluorescence population, resulting in the increase in the green/red ratio of 3.2- and 6.6-fold for PA1 cells following 2.5 and $5 \mu \mathrm{M}$ Siomycin A treatment, respectively, compared with that in the untreated control group $(\mathrm{P}<0.05$ Fig. $3 \mathrm{~A})$, and an increase of 5.3- and 8.9-fold in OVCAR3 cells with the two doses of Siomycin A, respectively, compared with those in the untreated control group ( $\mathrm{P}<0.05$ Fig. 4A), which indicated the loss of the mitochondrial membrane potential. The decrease in the mitochondrial membrane potential is associated with the release of cytochrome $c$ in the cytosol (26). Thus, the levels of cytochrome $c$ in the cytosol were determined in the present study by western blotting (Fig. 3B), and the results demonstrated that with increasing concentrations of Siomycin A, the protein levels of cytosolic cytochrome $c$ increased significantly in PA1 cells $(\mathrm{P}<0.05$ Fig. $3 \mathrm{C})$. Siomycin A treatment 

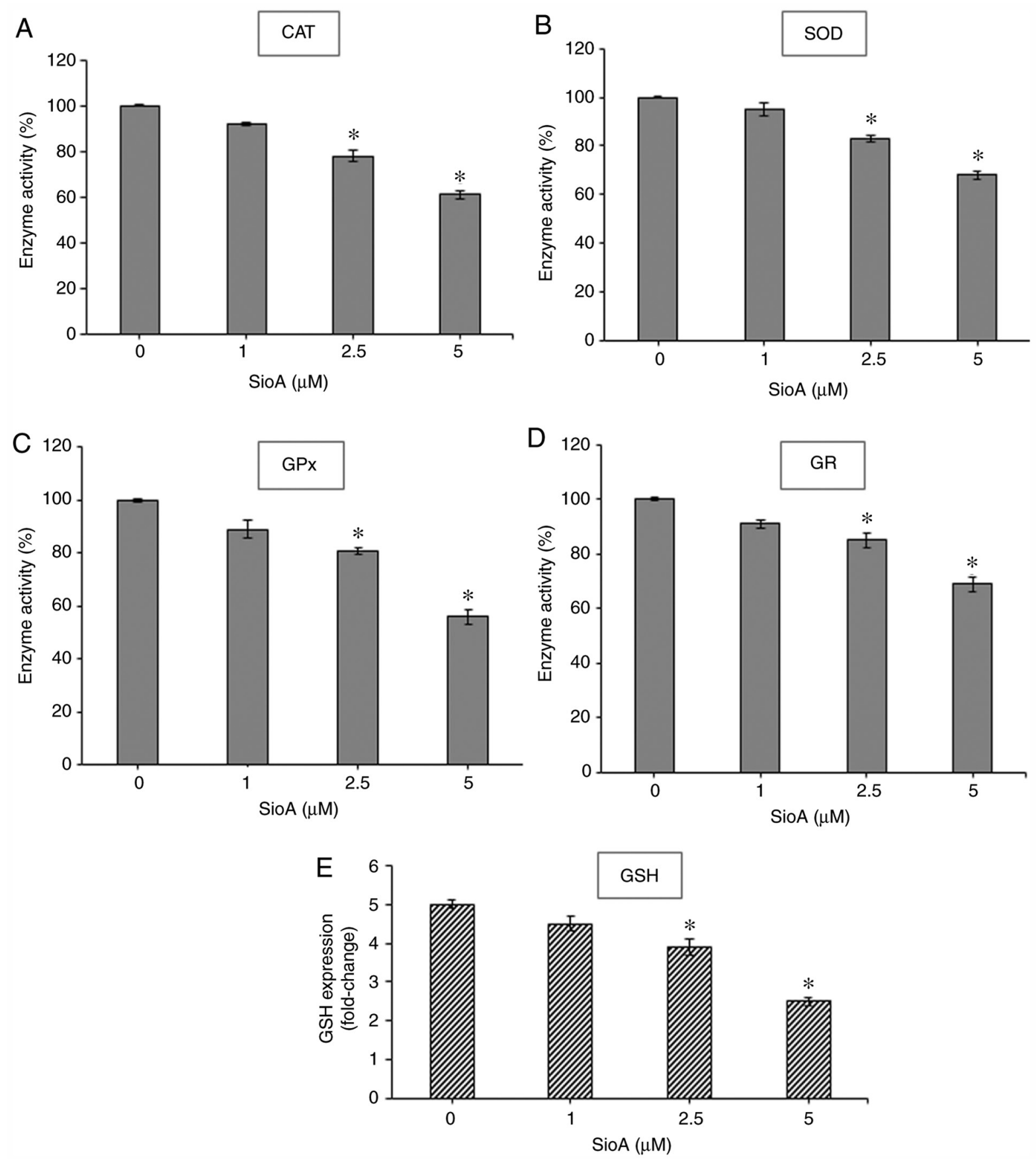

Figure 6. SioA suppresses antioxidant enzyme activity and intracellular GSH content of PA1 cells. (A-E) PA1 cells were incubated with $1,2.5$ and $5 \mu \mathrm{M}$ SioA for $24 \mathrm{~h}$, and antioxidant enzyme activities from cell extracts were spectrophotometrically assessed for (A) CAT, (B) SOD, (C) GPx, (D) GR and (E) GSH. n=3. "P<0.05 vs. $0 \mu \mathrm{M}$ SioA. SioA, Siomycin A; CAT, catalase; SOD, superoxide dismutase; GPx. glutathione peroxidase; GR, glutathione reductase; GSH, glutathione.

also resulted in the alterations of the expression levels of the proapoptotic protein Bax and the antiapoptotic protein Bcl-2; the upregulation of $\mathrm{Bax}(\mathrm{P}<0.05)$ and the downregulation of Bcl-2 $(\mathrm{P}<0.05)$ in PA1 cells treated with Siomycin A compared with those in the untreated cells, as demonstrated by western blotting, indicated an altered $\mathrm{Bax} / \mathrm{Bcl}-2$ ratio, suggesting that apoptosis was triggered (Fig. 3B and C). The activation of Bax leads to functional translocation of Bax to the mitochondria, increasing the permeability of the mitochondrial membrane, and thus facilitating the translocation of mitochondrial cytochrome $c$ into the cytosol pool (27). This augmented release of cytochrome $c$ serves a crucial role in increasing the levels of caspase-3, which leads to apoptosis by further activating the other caspases (27). In the present study, increased levels of Bax were observed with increases of cytochrome $c$ in the cytosol as well as the protein levels of caspase-3 $(\mathrm{P}<0.05)$ following Siomycin A treatment compared with those in the untreated cells, and the effects were observed in a dose-dependent fashion (Fig. 3C and D). Similar results were observed for the pro- and antiapoptotic proteins in OVCAR3 cells where the levels of $\operatorname{Bax}(\mathrm{P}<0.05)$, cytochrome $c(\mathrm{P}<0.05)$ and cleaved caspase-3 $(\mathrm{P}<0.05)$ were increased, and the levels of $\mathrm{Bcl}-2(\mathrm{P}<0.05)$ were reduced significantly following Siomycin A treatment (Fig. 4B and C). These results suggested that 

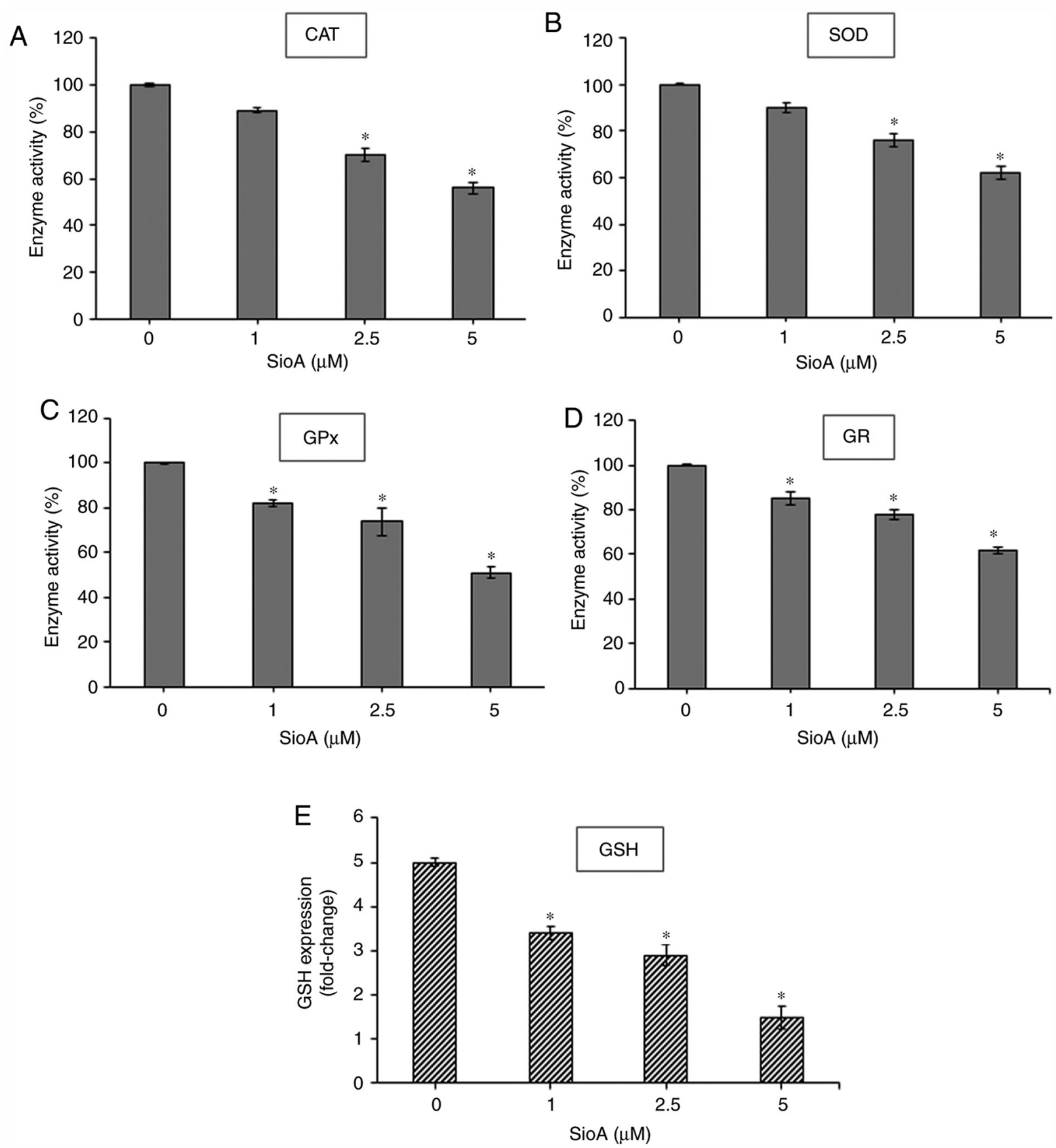

Figure 7. SioA suppresses antioxidant enzyme activity and intracellular GSH content of OVCAR3 cells. (A-E) OVCAR3 cells were incubated with $1,2.5$ and $5 \mu \mathrm{M}$ SioA for $24 \mathrm{~h}$, and antioxidant enzyme activities from cell extracts were spectrophotometrically assessed for (A) CAT, (B) SOD, (C) GPx, (D) GR and (E) GSH. n=3. "P<0.05 vs. $0 \mu$ M SioA. SioA, Siomycin A; CAT, catalase; SOD, superoxide dismutase; GPx. glutathione peroxidase; GR, glutathione reductase; GSH, glutathione.

Siomycin A may target the mitochondria of OC cells to induce caspase-mediated cell death.

Siomycin A treatment induces ROS generation in OC cells. Among the limited number of studies that have reported the activity of Siomycin A on cancer cells, ROS generation has not been clearly indicated as a mechanism of Siomycin A-induced cell death. Therefore, the present study investigated whether Siomycin A enhanced ROS generation in OC cells. The results demonstrated that DCF fluorescence, which is a standard indicator of cellular ROS generation, was significantly increased following Siomycin A treatment in
PA1 and OVCAR3 cells $(\mathrm{P}<0.05$ with peak increases at $24 \mathrm{~h}$ (Fig. 5A and C) and with a $5-\mu \mathrm{M}$ dose (Fig. 5B and D) in the two cell lines compared with those in the untreated cells. The generation of ROS is one of the key mechanisms of anticancer agents against various types of cancer cells (28), and the results of the present study demonstrated that Siomycin A is may be a potent ROS generator in OC cells, disrupting the cellular homeostasis in these cells and eventually leading to cell death.

Siomycin A treatment reduces antioxidant enzyme activity and GSH content in OC cells. Since the production of antioxidant 
A<smiles>C1CC[Tl]C1</smiles>

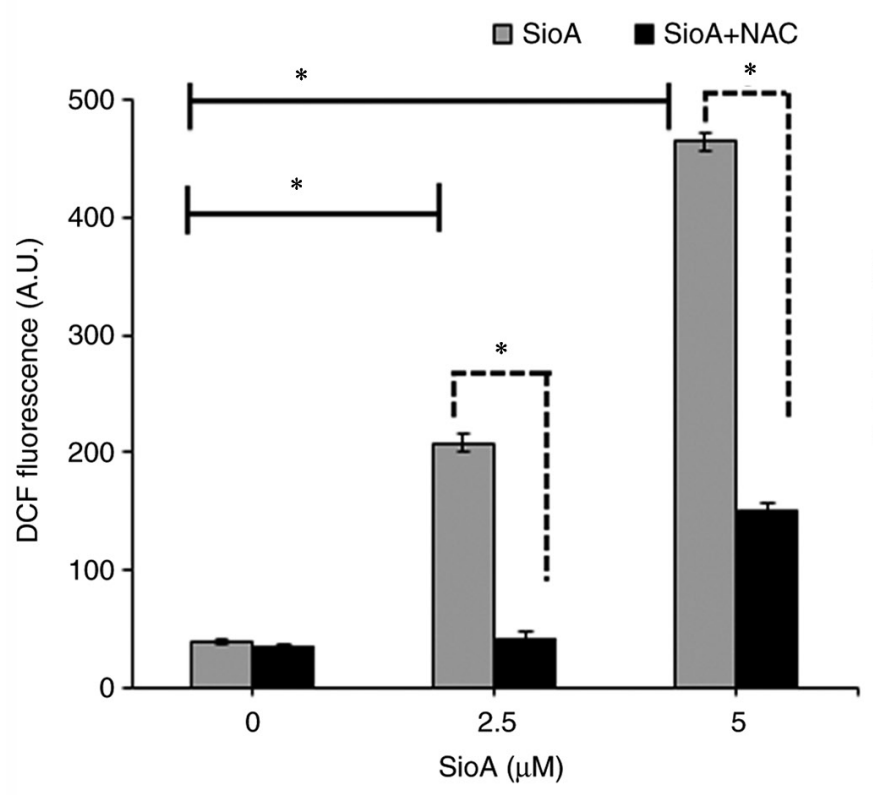

C

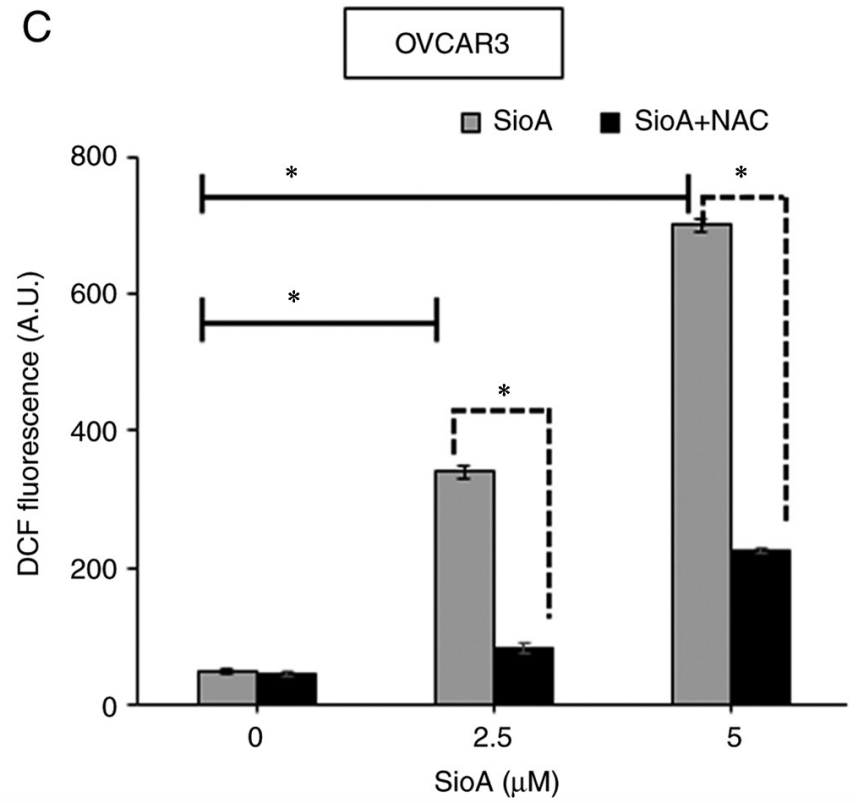

B
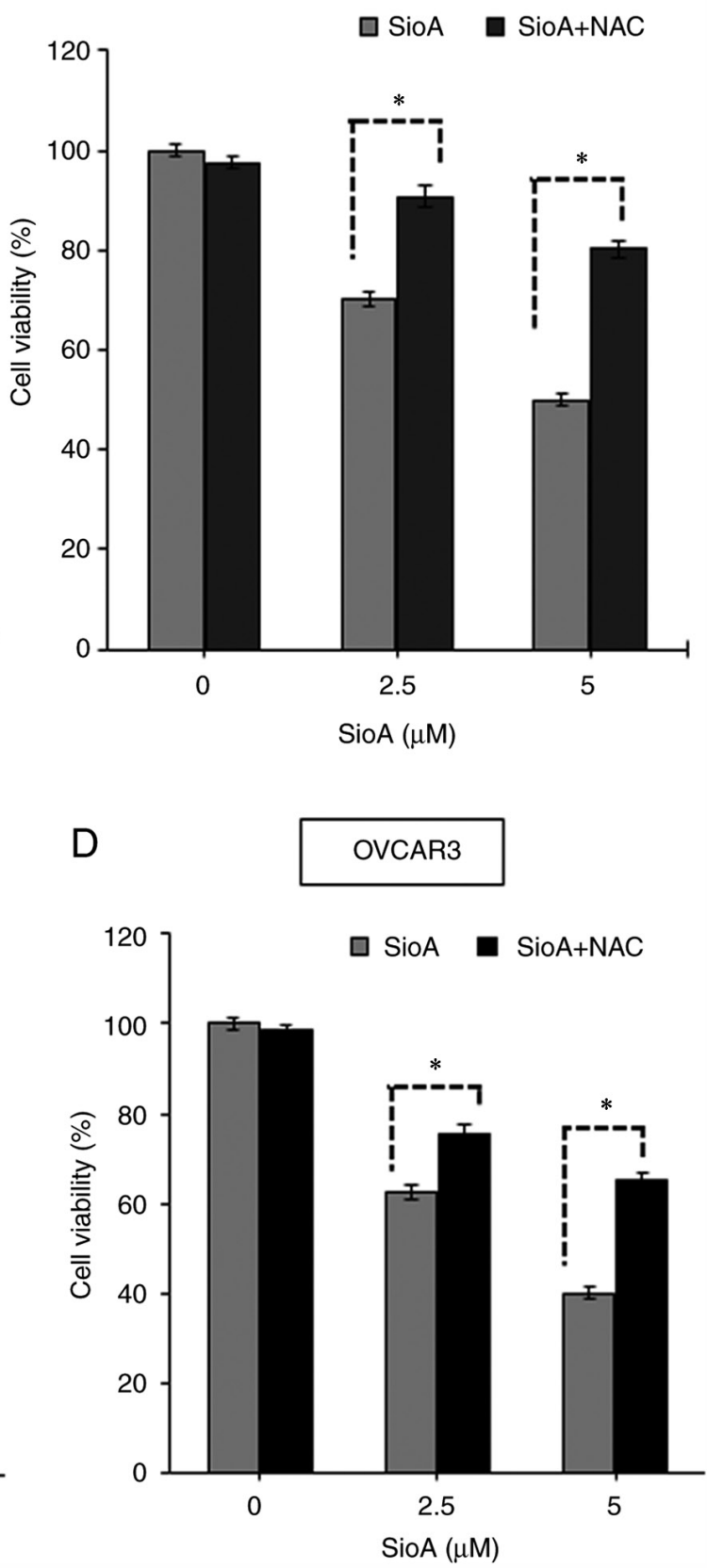

Figure 8. NAC ameliorates the SioA-induced cytotoxicity in ovarian cancer cells. (A) Determination of cellular ROS by DCF fluorescence assay in PA1 cells treated with 2.5 and $5 \mu \mathrm{M}$ SioA with or without NAC using fluorimetry. (B) The viability of PA 1 cells treated with 2.5 and $5 \mu \mathrm{M}$ SioA for $24 \mathrm{~h}$ with or without pretreatment with $200 \mu \mathrm{M}$ NAC. (C) Determination of cellular ROS by DCF fluorescence assay in OVCAR3 cells treated with 2.5 and $5 \mu$ M SioA with or without NAC using fluorimetry. (D) The viability of OVCAR3 cells treated with 2.5 and $5 \mu \mathrm{M}$ SioA for $24 \mathrm{~h}$ with or without pretreatment with $200 \mu \mathrm{M}$ NAC. $\mathrm{n}=3$. ${ }^{*} \mathrm{P}<0.05$. NAC, N-acetylcysteine; SioA, Siomycin A; ROS, reactive oxygen species; DCF, dichlorodihydrofluorescein.

enzymes is a key regulator of oxidative stress response (29), the present study evaluated the levels of major antioxidant enzymes that may be effective in detoxification of electrophilic and oxidative species in Siomycin A-treated OC cells. Treatment of PA1 and OVCAR3 cells (Figs. 6 and 7, respectively) with $1,2.5$ and $5 \mu \mathrm{M}$ Siomycin A for $24 \mathrm{~h}$ significantly reduced the levels of the antioxidant enzymes CAT $(\mathrm{P}<0.05$; Fig. 6A; $\mathrm{P}<0.05$; Fig. 7A), SOD ( $\mathrm{P}<0.05$; Fig. 6B; $\mathrm{P}<0.05$; Fig. 7B), GPx $(\mathrm{P}<0.05$; Fig. 6C; $\mathrm{P}<0.05$; Fig. $7 \mathrm{C})$ and $\mathrm{GR}(\mathrm{P}<0.05$; Fig. $6 \mathrm{D}$ and 7D) compared with those in the untreated control cells.
Combined with the aforementioned increases of ROS levels, these results indicated that Siomycin A may inactivate the antioxidant machinery in OC cells, leading to an uninhibited increase of ROS that causes the loss of cell viability and cell death.

The antioxidant enzymes GPx and GR form a well-regulated system to maintain the intracellular levels of GSH, which is the major non-protein thiol that acts as an antioxidant and a redox regulator in cells (30). Thus, the present study estimated the intracellular GSH levels and demonstrated that treatment 
A

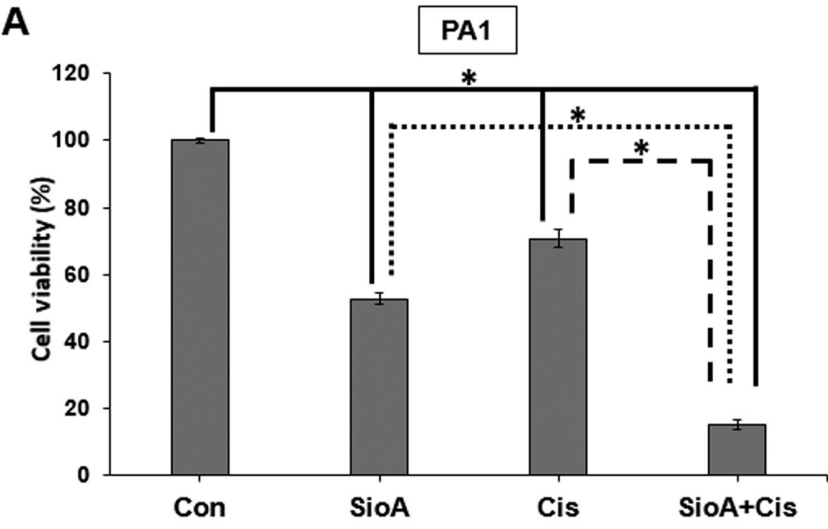

B

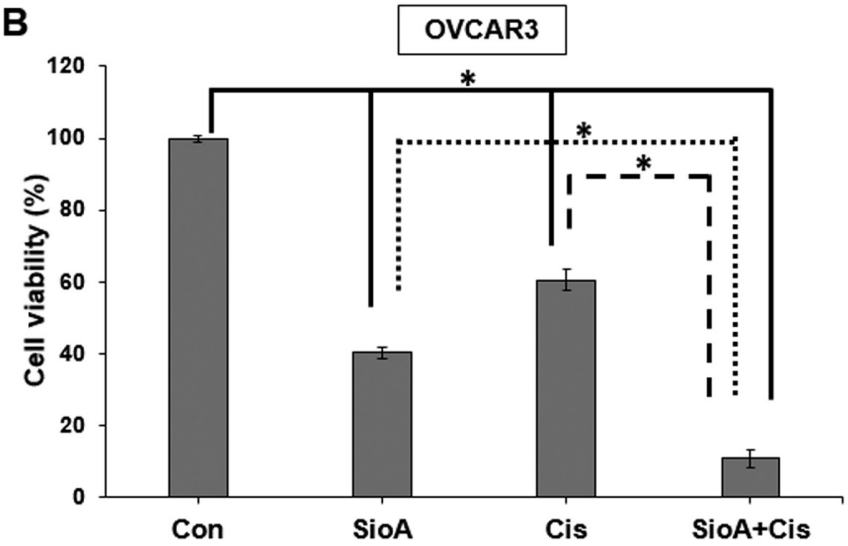

Figure 9. Co-treatment of ovarian cancer cells with SioA and the conventional anticancer drug Cis. (A) The effects of co-treatment of PA1 cells with $5 \mu \mathrm{M}$ SioA and $15 \mu \mathrm{M}$ Cis at $48 \mathrm{~h}$ were assessed by cell viability assay. (B) The effects of co-treatment of OVCAR3 cells with $5 \mu \mathrm{M}$ SioA and $10 \mu \mathrm{M}$ Cis at $48 \mathrm{~h}$ were assessed by cell viability assay. $\mathrm{n}=3 .{ }^{*} \mathrm{P}<0.05$ vs. Con. SioA, Siomycin A; Cis, cisplatin; Con, control.

with Siomycin A significantly decreased GSH levels in PA1 ( $\mathrm{P}<0.05$; Fig. 6E) and OVCAR3 ( $<<0.05$; Fig. 7E) cells compared with the untreated control sets. Therefore, Siomycin A may be as a redox-active compound that alters the levels of intracellular GSH to regulate redox signaling. High ROS levels cannot be balanced by the decreasing antioxidant enzyme status in the Siomycin A-treated OC cells, creating an imbalance in redox homeostasis and promoting cancer cell death.

NAC attenuates Siomycin A-mediated cytotoxicity in $O C$ cells. To determine whether ROS generation may be a potent cytotoxic mechanism in Siomycin A-treated OC cells, pretreatment with the standard antioxidant $200 \mu \mathrm{M} \mathrm{NAC}$ for $6 \mathrm{~h}$ was performed prior to treatment with Siomycin A. The results demonstrated that treatment of PA1 cells with $\mathrm{NAC}+$ Siomycin A significantly reduced the ROS levels by 4.24 -fold in the $\mathrm{NAC}+2.5 \mu \mathrm{M}(\mathrm{P}<0.05$ and 9.4 -fold in the $\mathrm{NAC}+5 \mu \mathrm{M}(\mathrm{P}<0.05)$ Siomycin A groups relative to Siomycin A treatment at the corresponding doses alone, as indicated by the DCF fluorescence measurement (Fig. 8A). In addition, the MTT assay revealed that pretreatment with NAC restored the viability of Siomycin A-treated PA1 cells by 2.5 fold in the $\mathrm{NAC}+2.5 \mu \mathrm{M}(\mathrm{P}<0.05)$ and 4.2 fold in the $\mathrm{NAC}+5 \mu \mathrm{M}(\mathrm{P}<0.05)$ Siomycin A groups compared with Siomycin A treatment alone at both doses (Fig. 8B). Similarly, in OVCAR3 cells, NAC + Siomycin A significantly reduced the ROS levels by $\sim 5$-fold in the $\mathrm{NAC}+2.5 \mu \mathrm{M}(\mathrm{P}<0.05)$ and $\sim 10$-fold in the NAC $+5 \mu \mathrm{M}(\mathrm{P}<0.05)$ Siomycin A groups relative to Siomycin A treatment alone at both concentrations (Fig. 8C). Pretreatment with NAC restored the viability of Siomycin A-treated OVCAR3 cells, as demonstrated by MTT assay, by $\sim 13 \%$ in the $\mathrm{NAC}+2.5 \mu \mathrm{M}(\mathrm{P}<0.05)$ and $\sim 25 \%$ in the NAC $+5 \mu \mathrm{M}(\mathrm{P}<0.05)$ Siomycin A groups compared with that in cells treated with Siomycin A alone at both doses (Fig. 8D). Therefore, ROS may serve a key role in Siomycin A-mediated cytotoxicity of OC cells, and administration of the antioxidant NAC abrogated this process and reversed the loss of cell viability.

Siomycin A and cisplatin inhibit the proliferation in $O C$ cells in combination. Since a number of novel drug candidates act synergistically with existing anticancer drugs to increase their efficacy in targeting cancer cells, the present study further aimed to determine whether Siomycin A may be paired with cisplatin, a drug used in OC treatment that may lead to tumors acquiring platinum resistance and result in a poor prognosis (31). We hypothesized that Siomycin A may sensitize OC cells to cisplatin therapy, therefore decreasing their chances of survival in a tumor. The results of the present study demonstrated that when PA1 cells were co-treated with $5 \mu \mathrm{M}$ Siomycin A and $15 \mu \mathrm{M}$ cisplatin, the cell viability was reduced to $15 \%$ of that in the control group $(\mathrm{P}<0.05$, which was lower compared with Siomycin A $(52 \%$; $\mathrm{P}<0.05)$ or cisplatin $(70 \% ; \mathrm{P}<0.05)$ treatment alone (Fig. 9A). OVCAR3 cells were highly susceptible to the co-treatment, as their viability was reduced to $10 \%$ of that in the control group by co-treatment with $5 \mu \mathrm{M}$ Siomycin $\mathrm{A}$ and $10 \mu \mathrm{M}$ cisplatin $\left(\mathrm{IC}_{50}\right.$ for OVCAR3; data not shown) $(\mathrm{P}<0.05)$, which was lower compared with Siomycin A $(40 \% ; \mathrm{P}<0.05)$ and cisplatin $(60 \%$; $\mathrm{P}<0.05)$ alone (Fig. 9B).

For the combination study, single doses of Siomycin A and cisplatin were selected against OC cells. Given that it is not possible to determine whether the effect is additive or synergistic from a single dose-combination, more doses of these two drugs need to be included in prospective studies to determine the combination index. Thus, these results demonstrated that co-treatment with Siomycin A and cisplatin significantly increased the viability inhibition in OC cells compared with monotherapy.

\section{Discussion}

Siomycin A is a thiazole-based antibiotic, isolated from an endophytic Actinomycin sp, derived from the medicinal plant Acanthopanax senticosus (32), which is effective against several malignancies, such as pancreatic cancer, glioblastoma and melanoma (32-35). The anticancer role of Siomycin A against various cancer cells is well documented. The IC50 of Syomyicn A was between $0.5-2 \mu \mathrm{M}$ against the cancer cell lines, such as K562 cells (leukemia), MiaPaca-2 cells (pancreatic cancer), MCF-7 cells (breast cancer) and A549 cells (lung adenocarcinoma) $(32,33)$. However, the anticancer property of siomycin A against ovarian cancer and its underlying molecular mechanism have not yet been investigated. Thus, the present study aimed to investigate the effect of Siomycin A on two 
ovarian cancer cell lines, PA1 and OVCAR3, and determine its underlying molecular mechanism. Treatment of PA1 and OVCAR3 cells with Siomycin A for $72 \mathrm{~h}$ resulted in the drastic reduction of cell viability, and the IC50 values were observed at 5 and $2.5 \mu \mathrm{M}$ doses of Siomycin A, respectively. Notably, Siomycin A effectively inhibited the viability and proliferation of OC cells, with limited toxicity on lung fibroblast WI 38 cells. Furthermore, Siomycin A induced apoptosis in OC cells by targeting the mitochondria, which resulted in the decline of mitochondrial membrane potential and release of cytochrome $c$ into the cytosol. In addition, the expression levels of pro-apoptotic proteins, such as Bax and caspase-3, significantly increased in OC cells treated with Siomycin A.

Treatment with Siomycin A increased ROS production in dose- and time-dependent manners, accompanied by inhibition of the cellular antioxidant machinery. The cellular toxicity of Siomycin A was enhanced in combination with cisplatin, suggesting that this drug combination may act as a potent redox-directed anticancer chemotherapy in targeting OC cells.

The present study is not without limitations. For example, animal studies were not performed to prove the anticancer effect of Siomycin A in in vivo conditions. However, based on the significant effects of Siomycin A on OC cells in the present study, it can be speculated that Siomycin A may be used as a candidate drug against OC.

\section{Acknowledgements}

Not applicable.

\section{Funding}

No funding was received.

\section{Availability of data and materials}

The datasets used and/or analyzed during the present study are available from the corresponding author upon reasonable request.

\section{Authors' contributions}

XS performed the experiments, analyzed the data and drafted the initial manuscript. FZ and XG performed the experiements and analyzed the data. FX conceptualized the project and drafted the initial manuscript. XS and FX confirmed the authenticity of all the raw data. All authors have read and approved the final manuscript.

\section{Ethics approval and consent to participate}

Not applicable.

\section{Patient consent for publication}

Not applicable.

\section{Competing interests}

The authors declare that they have no competing interests.

\section{References}

1. Zhang Y, Luo G, Li M, Guo P, Xiao Y, Ji H and Hao Y: Global patterns and trends in ovarian cancer incidence: Age, period and birth cohort analysis. BMC Cancer 19: 984, 2019.

2. Reid BM, Permuth JB and Sellers TA: Epidemiology of ovarian cancer: A review. Cancer Biol Med 14: 9-32, 2017.

3. Webb PM and Jordan SJ: Epidemiology of epithelial ovarian cancer. Best Pract Res Clin Obstet Gynaecol 41: 3-14, 2017.

4. Pavlik EJ, Smith C, Dennis TS, Harvey E, Huang B, Chen Q, Piecoro DW, Burgess BT, McDowell A, Gorski J, et al: Disease-specific survival of type I and type II epithelial ovarian cancers-stage challenges categorical assignments of indolence \& aggressiveness. Diagnostics (Basel) 10: E56, 2020.

5. Momenimovahed Z, Tiznobaik A, Taheri S and Salehiniya H: Ovarian cancer in the world: Epidemiology and risk factors. Int J Womens Health 11: 287-299, 2019.

6. Ottevanger PB: Ovarian cancer stem cells more questions than answers. Semin Cancer Biol 44: 67-71, 2017.

7. Cornelison R, Llaneza DC and Landen CN: Emerging therapeutics to overcome chemoresistance in epithelial ovarian cancer: A mini-review. Int J Mol Sci 18: 2171, 2017.

8. Bast RC Jr, Hennessy B and Mills GB: The biology of ovarian cancer: New opportunities for translation. Nat Rev Cancer 9: 415-428, 2009.

9. Nakano I, Joshi K, Visnyei K, Hu B, Watanabe M, Lam D, Wexler E, Saigusa K, Nakamura Y, Laks DR, et al: Siomycin A targets brain tumor stem cells partially through a MELK-mediated pathway. Neuro Oncol 13: 622-634, 2011.

10. Koh B, Jeon H, Kim D, Kang D and Kim KR: Effect of fibroblast co-culture on the proliferation, viability and drug response of colon cancer cells. Oncol Lett 17: 2409-2417, 2019.

11. Shen X, Mustafa M, Chen Y, Cao Y and Gao J: Natural thiopeptides as a privileged scaffold for drug discovery and therapeutic development. Med Chem Res 28: 1063-1098, 2019.

12. Tüfekçi Ö, Yandım MK, Ören H, İrken G and Baran Y: Targeting FoxM1 transcription factor in T-cell acute lymphoblastic leukemia cell line. Leuk Res 39: 342-347, 2015.

13. Hou Y, Zhu Q, Li Z, Peng Y, Yu X, Yuan B, Liu Y, Liu Y, Yin L, Peng Y, et al: The FOXM1-ABCC5 axis contributes to paclitaxel resistance in nasopharyngeal carcinoma cells. Cell Death Dis 8: e2659, 2017.

14. Gartel AL: A new target for proteasome inhibitors: FoxM1. Expert Opin Investig Drugs 19: 235-242, 2010.

15. Nowak A, Zakłos-Szyda M, Żyżelewicz D, Koszucka A and Motyl I: Acrylamide decreases cell viability, and provides oxidative stress, DNA damage, and apoptosis in human colon adenocarcinoma cell line caco-2. Molecules 25: 368, 2020.

16. Maity G, De A, Das A, Banerjee S, Sarkar S and Banerjee SK: Aspirin blocks growth of breast tumor cells and tumor-initiating cells and induces reprogramming factors of mesenchymal to epithelial transition. Lab Invest 95: 702-717, 2015.

17. Harshkova D, Zielińska E and Aksmann A: Optimization of a microplate reader method for the analysis of changes in mitochondrial membrane potential in Chlamydomonas reinhardtii cells using the fluorochrome JC-1. J Appl Phycol 31: 3691-3697, 2019.

18. Halliwell B and Whiteman M: Measuring reactive species and oxidative damage in vivo and in cell culture: How should you do it and what do the results mean? Br J Pharmacol 142: 231-255, 2004.

19. Beers RF Jr and Sizer IW: A spectrophotometric method for measuring the breakdown of hydrogen peroxide by catalase. J Biol Chem 195: 133-140, 1952.

20. Marklund S and Marklund G: Involvement of superoxide anion radical in the autoxidation of pyrogallol and a convenient assay for superoxide dismutase. Eur J Biochem 47: 469-474, 1974.

21. Zhu H, Zhang L, Itoh K, Yamamoto M, Ross D, Trush MA, Zweier JL and Li Y: Nrf2 controls bone marrow stromal cell susceptibility to oxidative and electrophilic stress. Free Radic Biol Med 41: 132-143, 2006.

22. Forman HJ, Zhang H and Rinna A: Glutathione: Overview of its protective roles, measurement, and biosynthesis. Mol Aspects Med 30: 1-12, 2009.

23. Das A, Chakrabarty S, Choudhury D and Chakrabarti G: 1 , 4-Benzoquinone (PBQ) induced toxicity in lung epithelial cells is mediated by the disruption of the microtubule network and activation of caspase-3. Chem Res Toxicol 23: 1054-1066, 2010.

24. Ishiguro T, Ishiguro M, Ishiguro R and Iwai S: Cotreatment with dichloroacetate and omeprazole exhibits a synergistic antiproliferative effect on malignant tumors. Oncol Lett 3: 726-728, 2012. 
25. Tipgomut $\mathrm{C}$, Wongprommoon $\mathrm{A}$, Takeo $\mathrm{E}$, Ittiudomrak $\mathrm{T}$, Puthong S and Chanchao C: Melittin induced g1 cell cycle arrest and apoptosis in chago-k1 human bronchogenic carcinoma cells and inhibited the differentiation of THP-1 cells into tumour-associated macrophages. Asian Pac J Cancer Prev 19: 3427-3434, 2018.

26. Bustamante J, Caldas Lopes E, Garcia M, Di Libero E, Alvarez E and Hajos SE: Disruption of mitochondrial membrane potential during apoptosis induced by PSC 833 and CsA in multidrug-resistant lymphoid leukemia. Toxicol Appl Pharmacol 199: 44-51, 2004.

27. Finucane DM, Bossy-Wetzel E, Waterhouse NJ, Cotter TG and Green DR: Bax-induced caspase activation and apoptosis via cytochromec release from mitochondria is inhibitable by Bcl-xL. J Biol Chem 274: 2225-2233, 1999.

28. Liou GY and Storz P: Reactive oxygen species in cancer. Free Radic Res 44: 479-496, 2010.

29. Valko M, Rhodes CJ, Moncol J, Izakovic M and Mazur M: Free radicals, metals and antioxidants in oxidative stress-induced cancer. Chem Biol Interact 160: 1-40, 2006.

30. Filomeni G, Rotilio G and Ciriolo MR: Cell signalling and the glutathione redox system. Biochem Pharmacol 64: 1057-1064, 2002.
31. Helm CW and States JC: Enhancing the efficacy of cisplatin in ovarian cancer treatment-could arsenic have a role. J Ovarian Res 2: 2, 2009.

32. Wang B, Wang W, Meng HY, Chen J and Yuan LJ: Effects and mechanism of siomycin $\mathrm{A}$ on the growth and apoptosis of MiaPaCa-2 cancer cells. Oncol Lett 18: 2869-2876, 2019.

33. Guo X, Liu A, Hua H, Lu H, Zhang D, Lin Y, Sun Q, Zhu X, Yan $\mathrm{G}$ and Zhao F: Siomycin a induces apoptosis in human lung adenocarcinoma A549 cells by suppressing the expression of foxm1. Nat Prod Commun 10: 1603-1606, 2015.

34. Radhakrishnan SK, Bhat UG, Hughes DE, Wang IC, Costa RH and Gartel AL: Identification of a chemical inhibitor of the oncogenic transcription factor forkhead box M1. Cancer Res 66: 9731-9735, 2006.

35. Lee VS, McRobb LS, Moutrie V, Santos ED and Siu TL: Effects of FOXM1 inhibition and ionizing radiation on melanoma cells. Oncol Lett 16: 6822-6830, 2018.

(c) (i) $(9)$ This work is licensed under a Creative Commons Attribution-NonCommercial-NoDerivatives 4.0 International (CC BY-NC-ND 4.0) License. 